\title{
A change in the wind? US public views on renewable energy and climate compared
}

\author{
Lawrence C. Hamilton ${ }^{1,4^{*}}$ D, Erin Bell ${ }^{2}$, Joel Hartter ${ }^{3,4}$ and Jonathan D. Salerno ${ }^{3}$
}

\begin{abstract}
Background: Renewable energy development is a necessary step toward climate change mitigation, so these topics have often been linked. In US public discourse, however, they have somewhat different profiles_climate change views are tied closely to partisan identity, whereas renewable energy exhibits more cross-cutting appeal, and sometimes more cross-cutting opposition as well. To what extent are such differences reflected in survey data tracking rates of change, respondent characteristics, and local or regional variations in public opinion on renewable energy and climate?

Methods: We explore similarities and differences in views of renewable energy and climate change using a unique collection of 18 US national or regional surveys totaling more than 14,000 interviews, conducted between 2011 and 2017. Individual surveys varied in context, content, and goals, but all asked two common energy and climate questions, which yield comparable and strikingly consistent results.

Results: Public support for renewable energy appears broader than acceptance of anthropogenic climate change (ACC), especially in a more conservative region. Despite local controversies, support for renewable energy in recent years rose faster than ACC acceptance on two regional surveys. Political divisions remain wide on both topics, but wider regarding climate change-particularly among college-educated respondents. Renewable energy views in counties with proposed or operating wind farms are not systematically different from those in other counties.
\end{abstract}

Conclusions: Overall, these results provide encouragement for promoting renewable energy in terms of its economic benefits, working around some of the political identity-based resistance to climate change mitigation. That approach could be most important in politically conservative regions where such resistance is strong.

Keywords: Climate change, Renewable energy, Wind, Solar, Survey, Public opinion

\section{Background}

Transitioning from fossil fuels to lower-carbon renewable energy sources presents the central challenge and most pressing requirement for mitigation of anthropogenic climate change. Consequently, the issues of renewable energy development and climate change often are linked through scientific, policy, and public discussions. In the USA, however, renewable energy appears to have somewhat broader public appeal [1-3]. That appeal partly reflects immediate economic benefits including jobs, cheaper energy, and income for landowners or managers. Less tangibly, some renewable sources (e.g., rooftop and

\footnotetext{
* Correspondence: Lawrence.Hamilton@unh.edu

'Department of Sociology, University of New Hampshire, Durham, NH 03824, USA

${ }^{4}$ Carsey School of Public Policy, University of New Hampshire, Durham, NH 03824, USA

Full list of author information is available at the end of the article
}

community solar) promise a sense of self-sufficiency that attracts people of diverse persuasions. Individual incentives include lower prices, growing accessibility, belief that renewable energy is environmentally better, and social modeling as people see their peers or other regions successfully adopting. Broader public acceptance of renewable energy leads to suggestions that renewable energy development should be advocated as a constructive action with or without reference to climate change [4-7].

But how different are the social bases of public support for renewable energy and views about climate change? A unique collection of 18 national and regional US surveys, all of which carried the same two energy and climate questions, allows systematic comparison of views on these issues across time, location, and respondent characteristics. We find broad similarities in the background characteristics of people who prioritize renewable 
energy development and those who accept the reality of anthropogenic climate change (ACC). There are some contrasts regarding the two issues as well: renewable energy development has somewhat higher public support, especially in a conservative region, and its support may be rising faster. More subtly, differences in the interaction between education and political party suggest that processes of partisan information-filtering operate less severely with renewable energy than with acceptance of ACC. These results provide qualified encouragement for promoting renewable energy in terms of its economic benefits, working around some of the political identity-based resistance to climate change mitigation.

Solar and wind power currently make up relatively small fractions, around 2.2 and $5.5 \%$ respectively, of US electricity generating capacity [8]. However, their importance is rapidly growing. Solar power (both concentrated industrial and distributed photovoltaics) contributed $39 \%$ of all new US capacity in 2016; another $26 \%$ came from wind power [9]. In terms of employment, solar and wind power industries grew 12 times faster than the US economy as a whole, with employment in both sectors well surpassing the declining coal industry [10]. Dramatic reductions in the cost of solar- and windgenerated electricity have made them economically more competitive, while rising concerns about climate change highlight their importance as low-carbon sources. Other factors including legislation, tax credits, community programs, new enterprises, and wider distribution networks add to renewable energy's consumer appeal-although some of these could be reversed by changes in government policy.

Immediate employment and economic benefits give renewable energy issues a different character from riskoriented discussions of anthropogenic climate change (ACC), but the two topics often are linked [11]. Reducing greenhouse gas emissions, hence slowing the pace of climate change, forms a major argument in favor of renewable energy development. While new industries or investments build up wind and solar, fossil fuel interests have incentives and means to oppose renewable energy development or else shift emphasis to other fossil fuels such as natural gas instead of coal. Politicians, politicized media, and the public often align their views on both topics according to general left/right orientation: renewable energy and the reality of ACC are more widely accepted among liberals and moderates, whereas fossil fuels and ACC denial have stronger conservative appeal. Thus, perceptions about renewable energy and climate become tied to sociopolitical identity, as dramatized in the 2016 US presidential campaign where the main parties took opposite positions on both [12]. Of course, such left/right alignment is socially constructed; there is nothing inherently liberal or conservative about wind turbines and oil wells, or the Earth's air and water.

Political identity dominates other individual characteristics in predicting climate change views among the US public. Gender and age effects are weaker but generally consistent: women and younger adults more often see ACC as a problem. Such relationships between climate views and individual characteristics have been extensively studied, with new work almost weekly [13-20]. Despite the diverse methods employed, analyzing different questions from samples collected at different times, core findings appear stable. The demographic predictors of climate change concern broadly resemble those of other environmentrelated topics explored by studies over the decades since Van Liere and Dunlap wrote about "the social bases of environmental concern"-although political divisions are much wider now [21].

Regarding climate change and other environmental issues, people with more education generally express higher concern. Education effects are complicated, however, by their interaction with politics. Concern increases with education among liberals and moderates, but does not increase and may even decrease with education among the most conservative [22-26]. Similar patterning occurs in analyses with objectively assessed science literacy or numeracy, or with subjectively assessed understanding, taking the place of education [25, 27-29]. Conceptual explanations for this class of interactions invoke information-filtering frameworks such as elite cues, confirmation bias, cultural cognition, biased assimilation, motivated reasoning, reinforcing spirals, and selective exposure [15, 30-39]. These frameworks share a common insight that people preferentially acquire information that reinforces their prejudices and sociopolitical identity. Better-educated individuals more actively filter information and are more cognizant of identity-appropriate positions, so educated partisans are the farthest apart.

The social bases of support for renewable energy development in general terms resemble those for concern about climate change and other environmental issues. Driven by practical interests, however, studies of public support for renewable energy often focus on specific places where development is occurring or proposed. At regional and local scales, different patterns emerge, as people who might be expected to favor renewable energy in general terms based on their values nevertheless oppose a specific development having impacts near where they live [40-42]. Such opposition is often labeled as NIMBY ("not in my backyard"), although some scholars reject that term as pejorative and unfairly simple [43, 44]. Wolsink (2007), for example, notes the importance of feelings about equity and fairness, along with visual impacts on the landscape, in shaping views 
toward local wind development [45]. Petrova (2016) distinguishes four broad categories of concern-visual/ landscape, environmental, socioeconomic, and procedural [46]. Specific issues include apprehensions about noise, impacts on wildlife, sense of place, engagement in process, and the degree of local vs. distant benefits. Research sometimes aims to identify particular communication or engagement strategies that reduce local opposition [47]. Unsurprisingly, a key factor affecting public support for renewable energy development is perception of local economic benefits [48-50].

In this paper, we examine key questions arising from discourse on renewable energy in the context of climate change. (1) Does the higher public support for renewable energy found in national surveys also occur locally, in places with controversial development? (2) Are views on these topics changing, and with similar directions and rates? (3) Do the same individual characteristics predict views on renewable energy and climate change, or are the former less politicized? (4) Net of individual characteristics, are there detectable differences in renewable energy views of residents in counties that have or have not experienced large-scale wind power development?

Addressing these questions requires broad, comparative data. We analyze a unique collection of 18 surveys with more than 14,000 respondents, conducted under four different projects over 2011 to 2017. Although these surveys differed in content and goals, they carried two common renewable energy and climate change questions-providing a resource for exploring individual, regional, and temporal dimensions of public views on renewable energy and climate change together.

\section{Methods}

Of the four survey projects covered, one (Polar, Environment, and Science; POLES) involves nationally representative US samples. The other three are regional, covering the state of New Hampshire, the North Country (a rural four-county region in northern New Hampshire, Vermont, and Maine), and northeast Oregon. Each of the regional studies involves areas that experienced economically significant manifestations of climate change during these years and also saw controversial development of wind power.

\section{Regional survey context}

Solar energy, mainly from distributed photovoltaics, contributes less than $1 \%$ of New Hampshire's electricity needs. The state's northern latitude and climate are less conducive to solar power than some sunnier locations, but the solar contribution has been rapidly growing. Around 54 MW of installed capacity existed in 2016, and it is projected to pass $260 \mathrm{MW}$ over the next 5 years [9]. The state's solar industry includes almost 80 companies, the majority involved with manufacturing. Demand from individual businesses and homeowners, encouraged by utility rebates, is driving this expansion.

New Hampshire hilltops provide locations favorable for wind turbines. The main sites currently operating are Lempster Mountain (Sullivan County), Granite Reliable Wind Farm (Coös County), and Groton Wind (Grafton County), which have a combined capacity around $170 \mathrm{MW}$. Additional wind farms have been proposed for Antrim (Hillsborough County) and Spruce Ridge (Grafton County), but these appear stalled after residents of nearby towns voted overwhelmingly against them. Primary concerns raised by opponents include negative impacts on property values, scenery, wildlife, and public health and safety (related to sound and shadow flicker from turbines) [51].

Other significant sources of renewable energy for New Hampshire are hydroelectric power and biomass burning. Together, these have a capacity over $600 \mathrm{MW}$, although these sources were not mentioned in our survey question. Tidal energy, which is mentioned in the New Hampshire question, is not yet operational in the state apart from the small-scale Living Bridge project in Portsmouth.

Coös and Grafton Counties in New Hampshire, along with Essex County in Vermont, and Oxford County in Maine, comprise our North Country region. This sparsely populated region was the focus of a separate, targeted survey involving 1650 interviews in the summer of 2017. Coös and Grafton wind developments have been mentioned above. Oxford County has about $70 \mathrm{MW}$ of wind capacity operating at two sites (Spruce Mountain and Record Hill), with local support encouraged by the resulting income [52]. Wind farms at large and small scales have been proposed in Essex County, but faced strong local opposition [53]. Thus, all of the North Country counties have experience with proposed or currently operating wind development.

The state of Oregon generates the majority of its own electricity from renewable sources and exports some to other states. Hydroelectric power comprises the largest fraction, but installed wind capacity exceeds $3100 \mathrm{MW}$. Installed solar capacity is over $260 \mathrm{MW}$ and, as in New Hampshire, has been rising steeply [9]. Northeast Oregon, the site of our Communities and Forests in Oregon (CAFOR) surveys, is a sparsely populated region (fewer than 3 people per $\mathrm{km}^{2}$ ) with a relatively dry climate. Substantial wind farms operate at Elkhorn Valley (Union County) and the Vansycle Ridge and Stateline projects in Umatilla County. One smaller project (Chopin, also in Umatilla County) has been approved but not yet completed. A proposal for a larger project at Antelope Ridge in Union County was withdrawn in 2013. Fifty-two percent in a vote among Union county residents went against this project. Local opponents cited wildlife and visual impacts, whereas proponents focused on the 
potential for tax revenues and employment-as well as freedom of people to do what they want on their own land, a salient value in this region. The developer described withdrawal as strictly a business decision, resulting from changes in California rules that made it harder to export electricity to that state [54]. An even larger project, Wheatridge Wind (500 MW), has been proposed for Morrow and Umatilla Counties.

The context for renewable energy development in both New England and Oregon involves rapid growth in distributed photovoltaics, although these do not yet make up a large fraction of electricity supply. Both regions also have a recent, high profile recent history of wind farm development, with some sites established but others successfully opposed. Homemade signs and local activism opposing development in Union County, Oregon, were noted by the CAFOR research team during field work in 2011. The controversy inspired placement of our renewable energy question on the first Oregon survey, and subsequently on many others.

\section{Four survey projects}

US Polar, Environment, and Science (POLES)

These nationwide US landline and cell telephone surveys were organized by University of New Hampshire and Columbia University researchers. Interviews involved two stages with separate random samples: before the US presidential elections in August $2016(n=704)$ and immediately afterwards in November/December $2016(n=707)$. Response rates in four subsamples of the POLES survey ranged from 15 to $30 \%$ (all response rates are calculated following AAPOR definition 4 [55]). The surveys asked mainly environment- and science-related questions. Preliminary results have been described in two reports $[12,56]$.

\section{New Hampshire Granite State Poll (GSP)}

These landline and cell telephone surveys interview independent random samples of New Hampshire residents four times each year. Along with standard background and political questions, the GSP often carries items about environment or science. New Hampshire responses on the environment/science questions commonly fall close to national benchmarks. Some recent New Hampshire/US data comparisons, and citations to other GSP research, are given by Hamilton [56, 57]. From July 2012 to October 2017, the GSP conducted 7064 interviews that included our renewable energy question. The median response rate over this period was $20 \%$.

Northeast Oregon Communities and Forests in Oregon (CAFOR) Under the CAFOR project, landline and cell telephone surveys involving separate random samples of northeast Oregon residents were conducted in three stages: September/October 2011 ( $n=1585$ from Baker, Union, and Wallowa Counties), August/October 2014 ( $n=1752$, from the same three counties along with Crook, Grant, Umatilla, and Wheeler Counties), and October/November 2015 ( $n=651$, repeating the seven counties from 2014) $[24,58-61]$. Response rates on the three CAFOR surveys range from 30 to $48 \%$.

\section{North Country}

This survey in summer 2017 involved random-sample cell phone and landline interviews with 1650 residents of four adjacent counties in northern New England: Coös and Grafton, New Hampshire; Essex, Vermont; and Oxford, Maine. Designed to assess changes in residents' perceptions of their rural communities, the survey (with a response rate of 19\%) replicated some questions from earlier surveys [62].

\section{Results}

Table 1 lists variables from these surveys that are analyzed here. Although each project had different frameworks and goals, they carried two standard questions on renewable energy and climate. Additionally, the surveys gathered respondent background information such as age, education, and political party.

\section{Renewable energy and climate change views}

The renewable energy question asks,

Which do you think should be a higher priority for the future of this country, increased exploration and drilling for oil, or increased use of renewable energy such as wind or solar?

Figure 1 shows the strong support for renewable energy across the most recent years of each project (2015 for CAFOR, 2016 for POLES, 2017 for GSP and North Country). ${ }^{1}$ Seventy-two percent of the national respondents, and 78 or $79 \%$ in the recent North Country and New Hampshire surveys, gave renewable energy higher priority. Even in northeast Oregon, which environmentally and politically tends to be much more conservative [60,63], 61\% prioritized renewable energy while only $26 \%$ chose increased exploration and drilling.

The surveys also carried a basic question on climate change:

Which of the following three statements do you think is more accurate? Climate change is happening now, caused mainly by human activities; climate change is happening now, but caused mainly by natural forces; or climate change is not happening now.

The US, New Hampshire, and North Country results are quite similar-64 to $66 \%$ agreement with the 
Table 1 Definitions of variables, with coding used for logit regression models in Table 2

Dependent variables
Renew—Which do you think should be a higher priority for the future
of this country, increased exploration and drilling for oil or increased
use of renewable energy such as wind or solar? (Response choices
rotated in interviews.)
Increased use of renewable energy such as (NH only: tidal,) wind or
solar (1)
Increased exploration and drilling for oil (0)
don't know/no answer (0)
Climate—Which of the following three statements do you think is more
accurate? (Response choices rotated in interviews.)
Climate change is happening now, caused mainly by human activities (1)
Climate change is happening now, but caused mainly by natural forces (0)
Climate change is NOT happening now (0)
don't know/no answer (0)
Respondent characteristics
Age—-Respondent's age in years, 18-96
Sex—Male (0) or female (1)
Education—High school or less (- 1), some college or technical school (0),
college graduate (1), or postgraduate (2)
Party—Democrat (- 1), Independent (0), Republican (1), or Tea Party
supporter (2, not asked on 2011 CAFOR survey)
Timing of survey
Election—US POLES survey only: pre-election (0) or post-election (1) 2016
Year-NH GSP and OR CAFOR surveys only: year from 2011 to 2017
Windev distinguishes between counties in the regional surveys that do
(1) or do not (0) contain currently operating or proposed wind power
developments. In New Hampshire, these are Coös, Grafton, and Sullivan
counties; in northeast Oregon, Umatilla, and Union counties. All of the
North Country counties (Coös, Grafton, Essex, and Oxford) include such
developments.

scientific consensus that climate change is happening now, caused mainly by human activities (Fig. 2). Twenty-five to $29 \%$ instead think climate is changing for natural reasons, while just 3 or $4 \%$ maintain that climate change is not happening now. ${ }^{2}$ Previous studies found that New Hampshire and nationwide responses tend to be similar on this question [16].

Northeast Oregon is a politically conservative region; in the 2012 presidential election, Barack Obama received only 22 to $34 \%$ of the votes from our CAFOR counties (compared with $51 \%$ nationwide or $52 \%$ in New Hampshire). County-level voting behavior correlates strongly with views on climate change [63], so there is correspondingly low agreement in this region that human activities are changing the climate $(42 \%$ on our 2015 survey). Many residents concede that climate is changing but attribute it to natural forces [64]. Although our renewable energy and climate change questions are not directly comparable with each other, we note that the gap between renewable energy and anthropogenic climate change responses is particularly wide in this conservative region (19 percentage points). The wide gap in Oregon, where majorities prioritize renewable energy but do not think ACC is real, suggests some degree of decoupling from left/right identity-as illustrated anecdotally in Fig. 3.

Earlier papers discussed perceptions and reality of climate changes in northeast Oregon $[24,60]$ and New Hampshire [63].

Figure 4 tracks results from the 18 surveys synthesized for this study. The two nationwide POLES surveys, conducted just before and after the 2016 election, exhibit a slight uptick in public support for renewable energy following the election of Donald Trump, who strongly promotes fossil fuel use instead. In northeast Oregon, support for renewable energy rose almost linearly by about 10 points through the surveys of 2011, 2014, and 2015. Twelve statewide New Hampshire surveys show a rise of more than 15 points from 2012 to 2017. The North Country results, involving four rural counties of New Hampshire, Maine, and Vermont, provide a single data point that fits with the statewide New Hampshire trend. $^{3}$

Taken together, the regional surveys suggest a gradual rather than event-driven rise in priority for renewable energy, in keeping with national trends [2]. In New Hampshire and Oregon, the rise occurred despite local controversies about wind development. The next section tests whether shifts in demographics or political orientation can account for these trends.

\section{Individual, temporal, and regional effects}

Table 2 summarizes results from eight logit regression models predicting support for renewable energy (renew) or acceptance of anthropogenic climate change (climate) from individual respondent characteristics: age, sex, education, political party, and education $\times$ party interaction. ${ }^{4}$ Where appropriate, indicators of survey timing are included as predictors too-before/after the 2016 election for POLES or year for the New Hampshire and Oregon surveys. Finally, with New Hampshire and Oregon, we include an indicator for counties that have experienced proposed or accomplished wind developments. Variable definitions and coding are given in Table 1.

Table 2 expresses predictor effects in terms of odds ratios (exponentials of logit coefficients), interpreted as multiplicative effects on the odds favoring renewable energy development, or anthropogenic climate change, per 1-unit increase in each predictor. For example, the odds ratio 1.352 for education in model 1 indicates that the odds of favoring renewable energy increase by about 


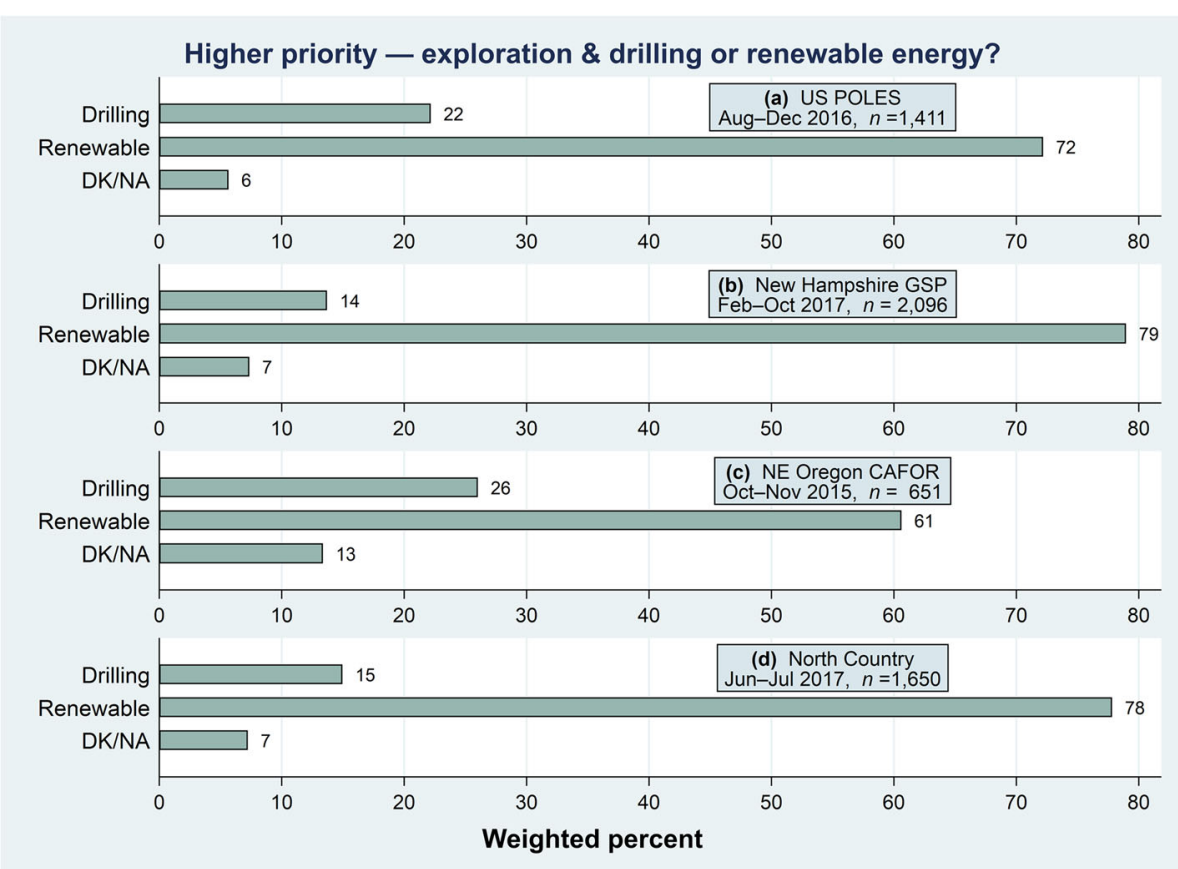

Fig. 1 Should increased exploration and drilling for oil, or increased use of renewable energy such as wind or solar, be a higher priority for the future of this country? Responses from most recent years of US POLES, New Hampshire GSP, NE Oregon CAFOR, and North Country survey projects

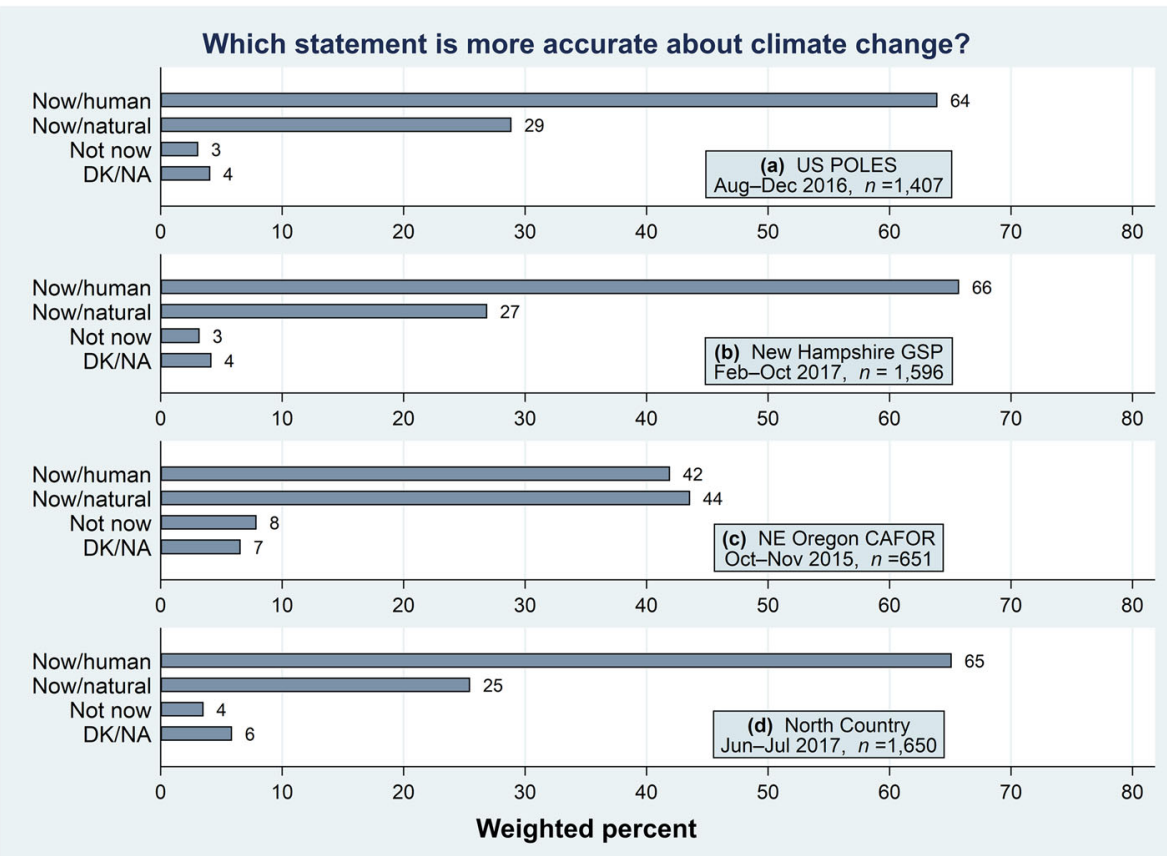

Fig. 2 Is climate change happening now, caused mainly by human activities? Is it happening now, but caused mainly by natural forces? Or is climate change not happening now? Responses from most recent years of US POLES, New Hampshire GSP, NE Oregon CAFOR, and North Country survey projects 


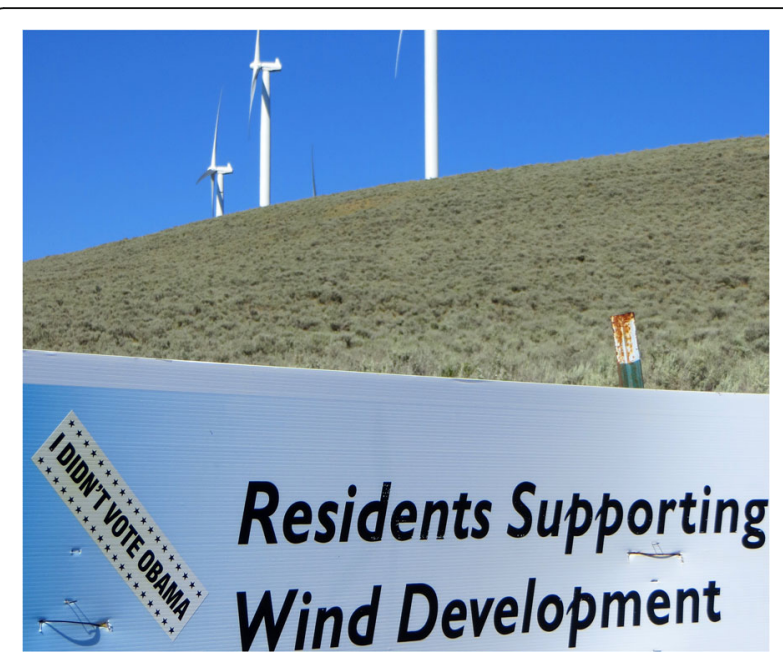

Fig. 3 Billboard with "I didn't vote Obama" sticker signals the political orientation of a wind power supporter in Oregon (L. Hamilton photo, July 2013)

$35 \%$ (multiplied by 1.352) with each 1-step increase in respondent education, other things being equal. This education effect is statistically significant at $p<0.01$, as determined by an adjusted Wald test. Probabilities from these tests are summarized by one to three stars (for $p<0.05$ to $p<0.001$ ) for each individual odds ratio in Table 2 . Similar notation in the row of $F$ statistics (likewise based on adjusted Wald tests) indicates that for all of these models, overall tests of the fitted model against a constant-only model yield $p$ values below 0.001 .
Descriptively, each model's fit is summarized by count $R^{2}$ and adjusted count $R^{2}$ statistics, adapted for these probability-weighted models [65].

The eight models in Table 2 describe four sets of data. The first two models involve the nationwide POLES survey, with an estimation sample of 1209 interviews. The dummy variable election is coded 0 for the preelection August stage and 1 for the post-election November/December stage, but this timing makes no difference in predicting either renew or climate. Age, education, and party, on the other hand, do affect renew and climate, and in similar directions for both dependent variables. Odds ratios greater than 1.0 correspond to "positive" effects, while those below 1.0 correspond to "negative" effects. Older respondents less often prioritize renewable energy or think anthropogenic climate change is real. Odds of prioritizing renewable energy or accepting ACC tend to be higher among respondents with more education and lower among those with more conservative political identities.

The education $\times$ party interaction effect on renew falls short of statistical significance $(p=0.09)$, although this interaction does significantly affect climate $(p<0.001)$. The interactions have a similar character for both renew and climate. Support for renewable energy, or acceptance of ACC, both tend to increase with education among Democratic and Independent respondents. Among Tea Party supporters, on the other hand, support for renewable energy does not rise with education, and acceptance of ACC actually declines (Fig. 5). Similar interactions have

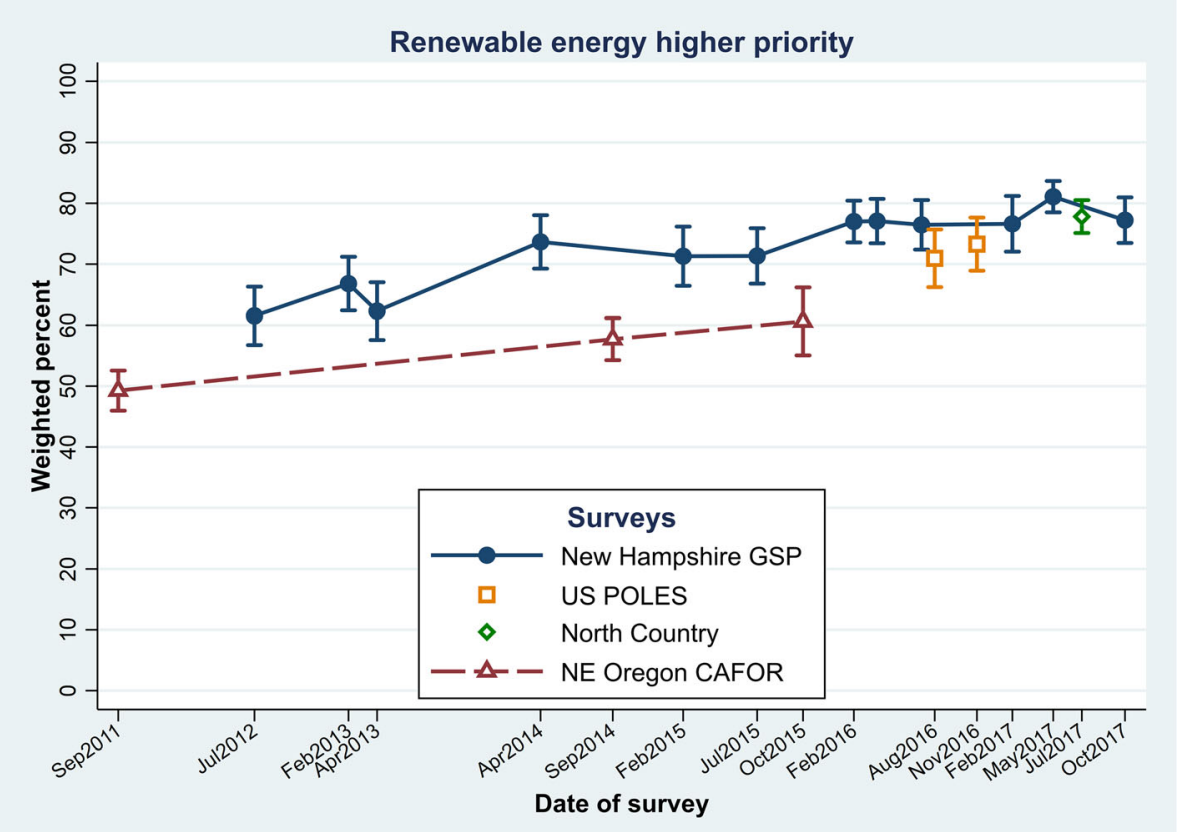

Fig. 4 Weighted percentages and 95\% confidence intervals for renewable energy higher priority, on two US and 16 regional surveys (combined $n=14,113)$ 
Table 2 Respondent characteristics and survey timing as predictors of high priority for renewable energy (renew), or think climate change is happening now, caused mainly by humans (climate). Values shown are odds ratios $\left(e^{b}\right)$ from weighted logit regressions with four survey datasets

\begin{tabular}{|c|c|c|c|c|c|c|c|c|}
\hline \multirow[b]{4}{*}{ Predictor } & \multicolumn{8}{|c|}{ Surveys and dependent variable } \\
\hline & \multicolumn{2}{|l|}{ US POLES } & \multicolumn{2}{|l|}{$\mathrm{NH}$ GSP } & \multicolumn{2}{|c|}{ OR CAFOR } & \multicolumn{2}{|c|}{ North Country } \\
\hline & \multicolumn{2}{|c|}{2016 (nationwide) } & \multicolumn{2}{|c|}{$2012-17$ (10 counties) } & \multicolumn{2}{|c|}{$2011-15$ (3 counties) } & \multicolumn{2}{|c|}{2017 (4 counties) } \\
\hline & 1. Renew & 2. Climate & 3. Renew & 4. Climate & 5. Renew & 6. Climate & 7. Renew & 8. Climate \\
\hline$\overline{\text { Age }}$ & $0.978^{* * *}$ & $0.977^{* * *}$ & $0.978^{* * *}$ & $0.985^{* * *}$ & $0.981^{* * *}$ & $0.984^{* * *}$ & $0.984^{* *}$ & $0.982^{* * *}$ \\
\hline Sex (female) & 0.984 & 1.300 & 1.001 & $1.292^{* *}$ & 0.992 & 1.004 & $1.537^{*}$ & 1.218 \\
\hline Education & $1.352^{* *}$ & $1.514^{* * *}$ & $1.174^{* * *}$ & $1.277^{* * *}$ & $1.187^{* *}$ & $1.230^{* *}$ & 1.073 & 0.931 \\
\hline Party & $0.480^{* * *}$ & $0.460^{* * *}$ & $0.437^{* * *}$ & $0.437^{* * *}$ & $0.364^{* * *}$ & $0.387^{* * *}$ & $0.498^{* * *}$ & $0.436^{* * *}$ \\
\hline$E d \times$ party & 0.873 & $0.676^{* * *}$ & $0.865^{* * *}$ & $0.785^{* * *}$ & 0.940 & $0.723^{* * *}$ & 0.901 & $0.781^{* *}$ \\
\hline Election & 1.083 & 0.896 & & & & & & \\
\hline Year & & & $1.160^{* * *}$ & $1.116^{* * *}$ & $1.125^{* *}$ & $1.100^{*}$ & & \\
\hline Windev & & & 0.959 & 1.094 & $0.743^{*}$ & 0.776 & & \\
\hline Est sample & 1209 & 1209 & 6143 & 4162 & 2357 & 2357 & 1451 & 1451 \\
\hline F statistic & $17.35^{* * *}$ & $23.17^{* * *}$ & $111.32^{* * *}$ & $95.36^{* * *}$ & $32.09^{* * * *}$ & $33.15^{* * *}$ & $19.86^{* * *}$ & $31.78^{* * *}$ \\
\hline Count $R^{2}$ & 0.77 & 0.75 & 0.79 & 0.73 & 0.70 & 0.73 & 0.78 & 0.71 \\
\hline Adj count $R^{2}$ & 0.18 & 0.32 & 0.20 & 0.34 & 0.38 & 0.58 & 0.02 & 0.18 \\
\hline
\end{tabular}

${ }^{*} p<0.05 ;{ }^{* *} p<0.01 ;{ }^{* * *} p<0.001$

been found in many other datasets across a wide range of environmental or science-related dependent variables [66].

Models 3 and 4 analyze the statewide New Hampshire surveys. Age, education, and party effects resemble those seen with the nationwide POLES data. Education $\times$ party interactions significantly affect both dependent variables in the New Hampshire data. Among self-identified Democrats and Independents, the probability of prioritizing renewable energy rises with education. Among non-Tea Party Republicans, education has no net effect. Among Tea Party supporters, however, higher education is associated with lower odds of supporting renewable

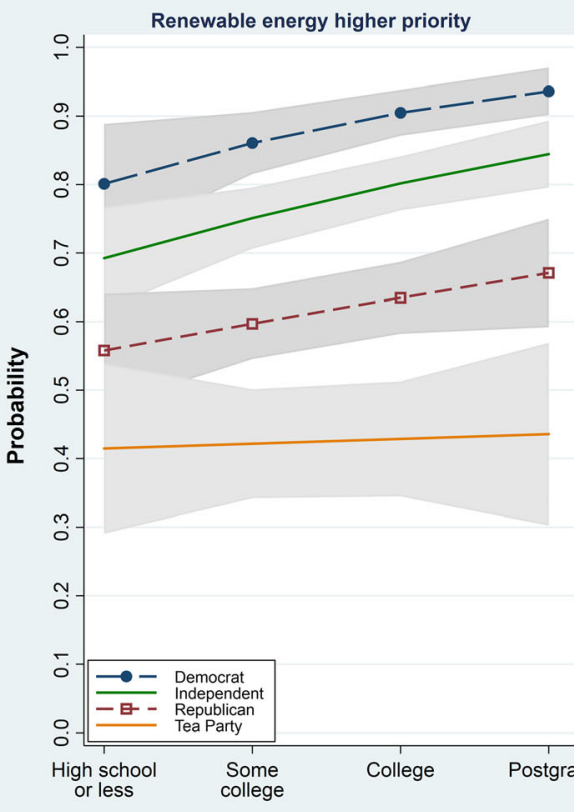

Climate change happening now, human caused
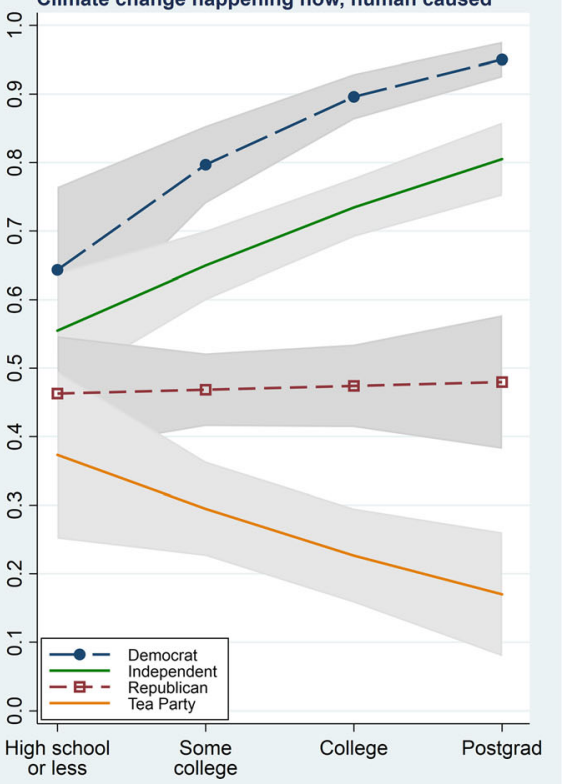

Fig. 5 Adjusted margins plots of educationxparty interaction effects on renewable energy priority (left) and anthropogenic climate change acceptance (right), from US survey models 1 and 2 in Table 2. Shading depicts 95\% confidence intervals 
energy, or accepting the reality of ACC. Significant main effects for education and party in models 3 and 4 (as elsewhere in Table 2) represent the effects of those variables when the other term equals zero-that is, the effect of education among political Independents (party $=0$ ) or the effect of political party among respondents with some college education (education $=0$ ).

Because these New Hampshire surveys occurred over a period from 2012 to 2017, we also include survey year among the predictors. Year exhibits significant and positive effects on both renew and climate. Thus, support for renewable energy and acceptance of anthropogenic climate change both increased over this period, and this increase is not explained by individual demographic and political factors. The rate of increase for renewable energy is steeper: odds rising by about $16 \%$ per year (multiplied by 1.160 ), compared with $12 \%$ per year (multiplied by 1.116 ) for acceptance of ACC.

The final predictor in the New Hampshire models of Table 2 is a variable indicating whether the respondent's county has large-scale wind power development. This distinction makes no detectable difference in support for renewable energy, or acceptance of anthropogenic climate change.

Models 5 and 6 describe northeast Oregon CAFOR surveys. For comparability, we restrict this analysis to a subset of the CAFOR data involving Baker, Union, and Wallowa counties. (Four other counties were surveyed, in addition to these three, in 2014 and 2015 only.) Also, the 2011 CAFOR survey permits only a three-party political coding, so that is used in models 5 and 6 unlike the others in Table 2 which employ 4-party coding. ${ }^{5}$ Age effects and the main effects of education and party are similar to those in US and New Hampshire surveys. After controlling for age, sex, education, and party, we still see significant year effects, meaning a rise in the odds of prioritizing renewable energy and accepting ACC. As in New Hampshire, the rise for renewable energy is somewhat steeper-odds increased by about $13 \%$ yearly, compared with $10 \%$ for ACC.

The Oregon models in Table 2 also include an indicator for counties with substantial wind development. This has a significant negative effect (odds ratio below 1.0), mainly reflecting lower support in Union county-site of an operating wind farm at Elkhorn Valley, but also the controversial Antelope Ridge proposal that was a focus of local opposition and withdrawn in $2013 .^{6}$

The final two models in Table 2 describe the North Country survey conducted in summer 2017 in four adjacent counties of northern New Hampshire, Vermont, and Maine. Age and party effects closely resemble those of other datasets. Education $\times$ party interactions affect views on climate change but not renewable energy, similar to the POLES and CAFOR results.

\section{Discussion}

Previous nationwide US surveys have noted rising public support for renewable energy development, with political divisions that are substantial but somewhat narrower than for climate change [66]. Given these realities, renewable energy development seemingly offers hope for working around some of the political resistance to climate change mitigation [5]. Development becomes most controversial, however, at local scales where impacts and benefits become more immediate [40,45]. Our analysis placed regional and national survey data in a side-by-side comparison, addressing four questions.

Does the higher public support for renewable energy found in national surveys also occur locally, in places with controversial developments? In each of the regional surveys, and also nationwide, the proportion of respondents who prioritize renewable energy exceeds those who accept the reality of anthropogenic climate change (Figs. 1 and 2). The gap between these proportions is wider on regional than national surveys and widest in the most conservative region.

Are views on these topics changing, and with similar directions and rates? In two regional time series, renewable energy support and ACC acceptance significantly increased over the years covered (2011-2015 or 2012-2017). In both cases, the trends are steeper for renewable energy than for ACC. Two nationwide and one single-shot regional survey yield data points consistent with these trends (Fig. 4).

Do the same individual characteristics predict views on renewable energy and climate change, or are the former less politicized? Renewable energy support and anthropogenic climate change acceptance are both predicted by age and (in all but the North Country survey) education. Both also are substantially politicized, as shown by strong party effects across all models in Table $2 .^{7}$ These issues differ most notably in terms of their education $\times$ party interactions. Odds ratios for the interaction effects are less than 1.0 across all eight models in Table 2, indicating that all point in the same direction: partisan divisions widen with education, so information elites stand the farthest apart. Within the pair of models for each survey, however, the education $\times$ party effects are weaker (closer to 1.0) for renew than for climate.

Explanations for this general class of interactions commonly invoke information-filtering processes, whether top-down as with elite cues (educated partisans more aware of positions taken by their political or media leaders) or bottom-up as with biased assimilation or motivated reasoning (educated partisans more actively acquire/reject information according to their prejudices). Information filtering could be a good thing if, for example, people preferentially favor scientific over non-scientific sources and understand which is which. Information 
filtering could also be a bad thing, if it involves rejection of scientific or otherwise well-grounded information that conflicts with political beliefs. Previous studies established what Table 2 confirms, that information filtering is particularly acute with regard to climate change. Our analysis shows that it occurs regarding renewable energy too, but less strongly. On that topic, people may be open to a wider range of information and less constrained by their political identity.

Net of background characteristics, are there detectable differences in renewable energy views of residents in counties that have or have not experienced large-scale wind power development? We find no systematic pattern of higher or lower support in counties with wind power development. The significant negative effect of the windev indicator in model 5 of Table 2 reflects a single county: Union County, Oregon, site of one successful development but another that was hotly contested and withdrawn. If we expand the Oregon analysis to include the four counties that were surveyed only in 2014 and 2015, instead of just the three counties surveyed in all 3 years (and thereby gain about 1200 observations), this windev odds ratio moves closer to 1.0 (going from to 0.72 to 0.83 ) and is no longer statistically significant.

Local opposition to wind farms probably operates at scales smaller than counties (or may cross county lines) and can depend on particularities of landscape and soundscape impacts, as well as the distribution of benefits. If wind projects are located in rural regions, while their energy and greatest economic benefits go somewhere else, this creates a sense of inequity and undermines some arguments for permitting local development. Our surveys do not resolve finer-scale geography or the perceptions about benefits, topics that could be pursued in future research.

\section{Conclusions}

Analysis of data from 18 surveys robustly confirms that support for renewable energy and acceptance of anthropogenic climate change have similar social bases with respect to age and education. Party divisions also are wide for both issues. Regarding climate change, the partisan gap widens with education. A similar widening pattern occurs with renewable energy but there it is milder and often not significant.

In two regions for which we have time series, and where development controversies have occurred, public support for renewable energy appears to be rising somewhat faster than acceptance of anthropogenic climate change. Renewable energy enjoys higher support overall, and the contrast between energy and climate views is greater in a more conservative region. This finding calls for replication and could have practical implications for renewable energy proponents in conservative regions.
The studied regions in the Intermountain West and northern New England have both have experienced harmful impacts related to climate change-including more frequent drought and wildfires (Oregon) or flooding (New England) and insect infestations affecting forests or human health [67-69]. Despite physical impacts, individual perceptions about climate change in those regions as elsewhere in the USA depend largely on politics $[60,63]$. Political opposition keeps agreement on meaningful greenhouse mitigation out of reach, despite growing risks. Renewable energy development, however, can to some degree be motivated without reference to climate change. Economic benefits to landowners or the local tax base appeal to some who reject global warming, even as others see the mitigation value. Local opposition to large-scale solar or wind developments can also be cross-cutting, however, driven partly by concern for landscapes that are central to rural life regardless of politics.

Any prospect for climate change mitigation requires rapid and substantial growth in low-carbon renewable sources of energy (such as wind and solar), while adapting the power grid to these sources and minimizing their manufacturing and waste footprints. US public acceptance of the reality of anthropogenic climate change has advanced only gradually, however, and the currently dominant political narrative at the federal level goes against this. In this context, promoting renewable energy in terms of practical benefits such as jobs and cheaper energy, independent of climate considerations, provides a valuable first step that is by no means sufficient, but in the near term may be necessary-particularly in conservative regions where much of the population rejects ACC. The similar social bases of renewable energy and climate change views place limitations on this strategy, but our findings give encouragement that it has some room to succeed.

\section{Endnotes}

${ }^{1}$ Probability weights calculated from each survey's sample characteristics and sampling design have been applied in Fig. 1 and all other analyses in this paper, to achieve more representative results.

${ }^{2}$ Fewer New Hampshire responses appear in Fig. 2b than in Fig. 1b because some GSP surveys with the renewables question did not also ask about climate. Results are similar but have wider confidence intervals if we restrict Figs. $1 \mathrm{c}$ and $2 \mathrm{c}$ to only the interviews that asked both.

${ }^{3}$ Coös and Grafton counties, which are represented (by different respondents and surveys) in both the New Hampshire and North Country datasets, together comprise only $9 \%$ of the state's population, and correspondingly $9 \%$ of the New Hampshire statewide sample. The economy and landscapes of these two northern counties differ from those of the state's populous southern tier. Consequently, 
there is limited redundancy between the coverage of New Hampshire and North Country projects.

${ }^{4}$ Political party is treated as a four-category ordinal variable, coded from -1 (Democrat) to +2 (Tea Party), for these regression models. An alternative approach, instead using a set of $\{0,1\}$ dummy variables, produces more complicated models with larger standard errors, while reaching substantially similar conclusions. For examples testing dummy-variable party indicators with 12 different dependent variables, see Figure 3 and Table 2 in Hamilton and Saito (2015).

${ }^{5}$ Analysis of the 2014 and 2015 CAFOR surveys only, based on all seven counties and with 4-party political coding (not shown), yields substantially similar conclusions to the 2011-2015, 3-county and 3-party analysis in models 5 and 6 of Table 2. We prefer the 2011-2015 3-county analysis for a more definitive test of change over time.

${ }^{6}$ Two alternative specifications were tested in the New Hampshire and Oregon analyses: indicators for counties where wind power development had been halted in the face of active opposition and indicators treating each county individually. Either alternative yields similarly weak county effects, while leaving the effects of other predictors almost unchanged.

${ }^{7} \mathrm{~A}$ simpler analysis, not described in the paper, confirms that although partisan gaps on both climate change and renewable energy are quite wide, they are wider for climate change across the most recent years of all four datasets. For example, in the 2016 US POLES surveys, the Democrat/Tea Party gap on climate change is 59 points, compared with 48 points on renewable energy. Corresponding gaps are 66/45 in the $2017 \mathrm{New}$ Hampshire surveys, 56/51 in the 2015 Oregon survey, and 48/31 in the 2017 North Country survey.

\section{Acknowledgements}

Sampling and interviews for all surveys were organized by the University of New Hampshire Survey Center. Some interviews for the POLES 1 and North Country surveys were conducted by the University of Northern Florida Public Opinion Research Laboratory.

\section{Funding}

Renewable energy and climate questions on the Granite State Poll have been supported by grants from the National Science Foundation (The Living Bridge IIP-1230460 and 1430260) and by the Carsey School of Public Policy and the Sustainability Institute at the University of New Hampshire. The Communities and Forests in Oregon (CAFOR) project is supported by the Agricultural and Food Research Initiative, US Department of Agriculture (201468002-21782 and 2010-67023-21705). The North Country survey was supported by a grant from the Neil and Louise Tillotson Fund of the New Hampshire Charitable Foundation. Support for the POLES surveys occurred through the PoLAR Partnership grant from the National Science Foundation (DUE-1239783), with additional help from the New Hampshire EPSCoR Safe Beaches and Shellfish project (IIA-1330641). Conclusions in this paper are those of the authors and do not necessarily represent the views of supporting organizations.

\section{Availability of data and materials}

The nationwide US POLES survey data analyzed for this paper (Figs. 1, 2, and 5 and Table 2) will be made available with publication. Time series summarizing results and confidence intervals from all 18 surveys (Fig. 4) will also be published. Individual-level data from the regional surveys is not publishable under humansubjects agreements, given the small populations of some rural counties involved. Stata do-files accomplishing the statistical analysis for these datasets will also be published, so other researchers can replicate our calculations for the POLES models.

\section{Authors' contributions}

$J H, E B$, and $L C H$ designed projects and questions for the regional surveys. $\mathrm{LCH}$ supervised all surveys, analyzed data, and drafted the rough version of this paper. $L C H, J H, E B$, and JDS contributed to writing and editing of the manuscript, and approved its final content.

\section{Authors' information}

LCH is professor of sociology and a senior fellow at the Carsey School of Public Policy at the University of New Hampshire.

$E B$, principal investigator/project director for the Living Bridge, is department chair and associate professor of Civil and Environmental Engineering at the University of New Hampshire.

$\mathrm{JH}$, principal investigator/project director of CAFOR, is associate professor and associate director for public education in the Environmental Studies Program, University of Colorado, and also a faculty fellow at the Carsey School of Public Policy, University of New Hampshire.

JDS is a postdoctoral research associate in the Environmental Studies Program and fellow in the Sustainability Innovation Lab of Colorado, University of Colorado.

\section{Ethics approval and consent to participate}

Research protocols for informed consent and the protection of human subjects on the 18 surveys described were individually reviewed and approved by the Institutional Review Board (IRB) at the University of New Hampshire.

\section{Consent for publication \\ Not applicable}

\section{Competing interests}

The authors declare that they have no competing interests.

\section{Publisher's Note}

Springer Nature remains neutral with regard to jurisdictional claims in published maps and institutional affiliations.

\section{Author details}

'Department of Sociology, University of New Hampshire, Durham, NH 03824, USA. ${ }^{2}$ Civil and Environmental Engineering, University of New Hampshire, Durham, NH 03824, USA. ${ }^{3}$ Environmental Studies Program, University of Colorado, Boulder, CO 80309, USA. ${ }^{4}$ Carsey School of Public Policy, University of New Hampshire, Durham, NH 03824, USA.

Received: 18 September 2017 Accepted: 20 February 2018

Published online: 02 April 2018

\section{References}

1. Ansolabehere S, Konisky DM (2014) Cheap and clean: how Americans think about energy in the age of global warming. MIT Press, Cambridge, MA

2. Kennedy B (2017) Two-thirds of Americans give priority to developing alternative energy over fossil fuels. Fact Tank, Pew Research. http://www. pewresearch.org/fact-tank/2017/01/23/two-thirds-of-americans-give-priorityto-developing-alternative-energy-over-fossil-fuels/. Accessed 26 Jan 2018

3. Stokes LC, Warshaw C (2017) Renewable energy policy design and framing influence public support in the United States. Nat Energy. https://doi.org/10. 1038/nenergy.2017.107

4. Cohen S (2017) Renewable energy with or without climate change. State of the planet. Earth Institute of Columbia University. http://blogs.ei.columbia. edu/2017/02/13/renewable-energy-with-or-without-climate-change/. Accessed 26 Jan 2018

5. Deaton J (2016) How to inspire action on climate in the age of Trump: a guide for advocates. Nexus Media. https://nexusmedianews.com/how-to-inspireaction-on-climate-in-the-age-of-trump-9dab4f8e7a6d. Accessed 26 Jan 2018 
6. Jackson R (2017) Forget about climate change. Scientific American. https:// blogs.scientificamerican.com/guest-blog/forget-about-climate-change/. Accessed 26 Jan 2018

7. Long N, Steinberger K (2016) Renewable energy is key to fighting climate change. Natural Resources Defense Council. https:/www.nrdc.org/experts/noahlong/renewable-energy-key-fighting-climate-change. Accessed 26 Jan 2018

8. EIA (2017) Electric power monthly with data for December 2016. U.S. Energy Information Administration. https://www.eia.gov/electricity/monthly/. Accessed 26 Jan 2018

9. SEIA (2017) Solar industry data. Solar Energy Industries Association. http:// www.seia.org/research-resources/solar-industry-data. Accessed 26 Jan 2018

10. DOE (2017) U.S. energy and jobs report. U.S. Department of Energy. https://energy.gov/downloads/2017-us-energy-and-employment-report. Accessed 26 Jan 2018

11. Edenhofer O, Pichs-Madruga R, Sokona S and 8 others (eds) (2011) Renewable energy sources and climate change mitigation: summary for policymakers and technical summary. Intergovernmental panel on Climate Change. https://www. ipcc.ch/pdf/special-reports/srren/SRREN_FD_SPM_final.pdf. Accessed 26 Jan 2018

12. Hamilton LC (2017) On renewable energy and climate, Trump voters stand apart. Durham, NH: Carsey School of Public Policy http://scholars.unh.edu/ carsey/293/. Accessed 26 Jan 2018

13. Shwom RL, McCright AM, Brechin SR, Dunlap RE, Marquart-Pyatt ST. Hamilton LC (2015) Public opinion on climate change. In: Dunlap and Brulle R (eds) Climate change and society: sociological perspectives. New York: Oxford University Press

14. Borick CP, Rabe BG (2010) A reason to believe: examining the factors that determine individual views on global warming. Soc Sci Q 91(3):777-800. https://doi.org/10.1111/j.1540-6237.2010.00719.x

15. Brulle RJ, Carmichael J, Jenkins CJ (2012) Shifting public opinion on climate change: an empirical assessment of factors influencing concern over climate change in the U.S., 2002-2010. Clim Chang 114(2):169-188. https:// doi.org/10.1007/s10584-012-0403-y

16. Hamilton LC, Hartter J, Lemcke-Stampone M, Moore DW, Safford TG (2015) Tracking public beliefs about anthropogenic climate change. PLoS One 10(9):e0138208. https://doi.org/10.1371/journal.pone.0138208

17. McCright AM, Dentzman K, Chartes M, Dietz T (2013) The influence of political ideology on trust in science. Environ Res Lett 8(4). https://doi.org/ 10.1088/1748-9326/8/4/044029

18. McCright AM, Dunlap RE, Xiao C (2014) Increasing influence of party identification on perceived scientific agreement and support for government action on climate change in the United States, 2006-12. Weather Climate Soc 6(2):194-201. https://doi.org/10.1175/WCAS-D-13-00058.1

19. Marquart-Pyatt ST, McCright AM, Dietz T, Dunlap RE (2014) Politics eclipses climate extremes for climate change perceptions. Glob Environ Chang 29: 246-257. https://doi.org/10.1016/j.gloenvcha.2014.10.004

20. Wiest SL, Raymond L, Clawson RA (2015) Framing, partisan predispositions, and public opinion on climate change. Glob Environ Chang 31:187-198. https://doi.org/10.1016/j.gloenvcha.2014.12.006

21. Van Liere KD, Dunlap RE (1980) The social bases of environmental concern: a review of hypotheses, explanations and empirical evidence. Public Opin Q 44(2):181-197. https://doi.org/10.1086/268583

22. Hamilton LC (2008) Who cares about polar regions? Results from a survey of U.S. public opinion. Arct Antarct Alp Res 40(4):671-678

23. Hamilton LC (2012) Did the Arctic ice recover? Demographics of true and false climate facts. Weather Climate Soc 4(4):236-249. https://doi.org/10. 1175/WCAS-D-12-00008.1

24. Hamilton LC, Hartter J, Safford TG, Stevens FR (2014) Rural environmental concern: effects of position, partisanship and place. Rural Sociol 79(2):257-281. https://doi.org/10.1111/ruso.12023

25. McCright AM, Dunlap RE (2011) The politicization of climate change and polarization in the American public's views of global warming, 2001-2010. Sociol Q 52(2):155-194. https://doi.org/10.1111/j.1533-8525.2011.01198.x

26. Shao W, Keim BD, Garland JC, Hamilton LC (2014) Weather, climate, and the economy: explaining risk perceptions of global warming, 2001-2010. Weather Clim Soc 6(1):119-134. https://doi.org/10.1175/WCAS-D-13-00029.1

27. Hamilton LC, Cutler MJ, Schaefer A (2012) Public knowledge and concern about polar-region warming. Polar Geogr 35(2):155-168. https://doi.org/10. 1080/1088937X.2012.684155

28. Kahan DM, Peters E, Wittlin M, Slovic P, Ouellette LL, Braman D, Mandel G (2012) The polarizing impact of science literacy and numeracy on perceived climate change risks. Nat Clim Chang 2(10):732-735. https://doi.org/10.1038/ NCLIMATE1547
29. Hamilton LC (2011) Education, politics and opinions about climate change: evidence for interaction effects. Clim Chang 104:231-242. https://doi.org/10. 1007/s10584-010-9957-8

30. Corner A, Whitmarsh L, Xenias D (2012) Uncertainty, scepticism and attitudes towards climate change: biased assimilation and attitude polarisation. Clim Chang 114(3-4):463-478. https://doi.org/10.1007/s10584-012-0424-6

31. Darmofal D (2005) Elite cues and citizen disagreement with expert opinion. Pol Res Q 58(3):381-395. https://doi.org/10.1177/106591290505800302

32. Feldman L, Maibach EW, Roser-Renouf C, Leiserowitz A (2012) Climate on cable: the nature and impact of global warming coverage on Fox News, CNN, and MSNBC. Int J Press/Politics 17(1):3-31. https://doi.org/10.1177/ 1940161211425410

33. Jasny L, Waggle J, Fisher DR (2015) An empirical examination of echo chambers in US climate policy networks. Nat Clim Chang 5(8):782-786. https://doi.org/10.1038/nclimate2666

34. Kahan DM, Jenkins-Smith H, Braman D (2011) Cultural cognition of scientific consensus. J Risk Res 14(2):147-174. https://doi.org/10.1080/13669877.2010.511246

35. Lord CG, Ross L, Lepper MR (1979) Biased assimilation and attitude polarization: the effects of prior theories on subsequently considered evidence. J Pers Soc Psychol 37(11):2098-2109. https://doi.org/10.1037/0022-3514.37.11.2098

36. Munro GD, Ditto PH (1997) Biased assimilation, attitude polarization, and affect in reactions to stereotype-relevant scientific information. Personal Soc Psychol Bull 23(6):636-653. https://doi.org/10.1177/ 0146167297236007

37. Slater MD (2007) The mutual influence of media selectivity and media effects and their impact on individual behavior and social identity. Commun Theory 17(3):281-303. https://doi.org/10.1111/j.1468-2885.2007.00296.x

38. Taber CS, Lodge M (2006) Motivated skepticism in the evaluation of political beliefs. Am J Polit Sci 50(3):755-769. https://doi.org/10.1111/j.1540-5907. 2006.00214.x

39. Zhao X (2009) Media use and global warming perceptions: a snapshot of the reinforcing spirals. Commun Res 36(5):698-723. https://doi.org/10.1177/ 0093650209338911

40. Batel S, Devine-Wright P (2015) Towards a better understanding of people's responses to renewable energy technologies: insights from social representations theory. Public Underst Sci 24(3):311-325. https://doi.org/10. $1177 / 0963662513514165$

41. Larson EC, Krannich RS (2016) 'A great idea, just not near me!' Understanding public attitudes about renewable energy facilities. Soc Nat Resour 29(12):1436-1451. https://doi.org/10.1080/08941920.2016.1150536

42. Swofford J, Slattery M (2010) Public attitudes of wind energy in Texas: local communities in close proximity to wind farms and their effect on decisionmaking. Energy Policy 38:2508-2519. https://doi.org/10.1016/j.enpol.2009.12.046

43. Devine-Wright P (2005) Beyond NIMBYism: towards an integrated framework for understanding public perceptions of wind energy. Wind Energy 8(2):125-139. https://doi.org/10.1002/we.124

44. Petrova MA (2013) NIMBYism revisited: public acceptance of wind energy in the United States. WIREs Climate Change 4(6):575-601. https://doi.org/10. 1002/wcc.250

45. Wolsink M (2007) Wind power implementation: the nature of public attitudes: equity and fairness instead of 'backyard motives'. Renew Sust Energ Rev 11:1188-1207. https://doi.org/10.1016/j.rser.2005.10.005

46. Petrova MA (2016) From NIMBY to acceptance: toward a novel framework—VESPA — for organizing and interpreting community concerns. Renew Energy 86:1280-1294. https://doi.org/10.1016/j.renene.2015.09.047

47. Hall N, Ashworth P, Devine-Wright P (2013) Societal acceptance of wind farms: analysis of four common themes across Australia case studies. Energy Policy 58:200-2008. https://doi.org/10.1016/j.enpol.2013.03.009

48. Bidwell D (2013) The role of values in public beliefs and attitudes towards commercial wind energy. Energy Policy 58:189-199. https://doi.org/10.1016/ j.enpol.2013.03.010

49. Dreyer SJ, Polis HJ, Jenkins LD (2017) Changing tides: acceptability, support, and perceptions of tidal energy in the United States. Energy Res Soc Sci 29: 72-83. https://doi.org/10.1016/j.erss.2017.04.013

50. Olson-Hazboun SK, Krannich RS, Robertson PG (2016) Public views on renewable energy in the Rocky Mountain region of the United States: distinct attitudes, exposure, and other key predictors of wind energy. Energy Res Soc Sci 21(2016):167-179. https://doi.org/10.1016/j.erss.2016.07.002

51. Foley M (2017) Antrim Wind project blown off course. The Keene Sentinel April 26. https://www.wind-watch.org/news/2017/04/27/antrim-windproject-blown-off-course/. Accessed 26 Jan 2018 
52. Richardson J (2012) Summers' new front against King may be in the wind. Portland Press Herald, September 1. http://www.pressherald.com/2012/09/01/ summers-new-front-against-king-may-be_2012-09-02/. Accessed 3 Aug 2017

53. Pannebaker A (2012) A dozen industrial wind farms under way in Vermont despite intense local opposition. Vtdigger, May 24. https:/vtdigger.org/ 2012/05/24/fourteen-industrial-wind-farms-planned-in-vermont-despiteintense-local-opposition/. Accessed 26 Jan 2018

54. Sickinger $T$ (2013) Antelope Ridge wind farm withdrawn by developers. The Oregonian, September 24. http://www.oregonlive.com/business/index.ssf/ 2013/09/edp_renewables_withdraws_contr.html . Accessed 26 Jan 2018

55. AAPOR (2006) Standard definitions: final disposition of case codes and outcome rates for surveys, 4th edn. American Association for Public Opinion Research, Lenexa, KS

56. Hamilton LC (2016) Where is the North Pole? An election-year survey on global change. Durham, NH: Carsey School of Public Policy. http://scholars. unh.edu/carsey/285/. Accessed 26 Jan 2018

57. Hamilton LC (2016) Public awareness of the scientific consensus on climate. Sage Open. https://doi.org/10.1177/2158244016676296

58. Boag AE, Hamilton LC, Hartter J, Stevens FR, Palace MW, Ducey MJ (2016) Shifting environmental concern in rural eastern Oregon: the role of demographic and place-based factors. Popul Environ. https://doi.org/10. 1007/s11111-016-0261-z

59. Hamilton LC, Hartter J, Stevens F, Congalton RG, Ducey M, Campbell M, Maynard D, Staunton M (2012) Forest views: Northeast Oregon survey looks at community and environment Oregon. Durham, NH: Carsey Institute. http://scholars.unh.edu/carsey/162/. Accessed 26 Jan 2018

60. Hamilton LC, Hartter J, Keim BD, Boag AE, Palace MW, Stevens FR, Ducey MJ (2016) Wildfire, climate, and perceptions in northeast Oregon. Reg Environ Chang. https://doi.org/10.1007/s10113-015-0914-y

61. Hartter J, Hamilton LC, Boag AE, Stevens FR, Ducey MJ, Christoffersen ND, Oester PT, Palace MW (2017) Does it matter if people think climate change is human caused? Climate Services. https://doi.org/10.1016/j.cliser.2017.06.014

62. Hamilton LC, Fogg LM, Grimm C (2017) Challenge and hope in the North Country. Durham, NH: Carsey School of Public Policy http://scholars.unh. edu/carsey/326/. Accessed 26 Jan 2018

63. Hamilton LC, Wake CP, Hartter J, Safford TG, Puchlopek A (2016) Flood realities, perceptions, and the depth of divisions on climate. Sociology 50: 913-933. https://doi.org/10.1177/0038038516648547

64. Boag AE, Hartter J, Hamilton LC, Christoffersen ND, Oester PT, Stevens FR, Palace MW, Ducey MJ (2018) Barriers to climate adaptation among private forest owners: insights from Eastern Oregon. in review

65. Long JS, Freese J (2014) Regression models for categorical dependent variables using Stata. Stata Press, College Station, TX

66. Hamilton LC, Saito K (2015) A four-party view of U.S. environmental concern. Environ Pol 24(2):212-227. https://doi.org/10.1080/09644016.2014.976485

67. Allen CC, Macalady AK, Chenchouni H, Bachelet D, McDowell N, Vennetier M, Kitzberger T, Rigling A, Breshears DD, Hogg EHT, Gonzalez P, Fensham R, Zhang Z, Castro J, Demidova N, Lim J-H, Allard G, Running SW, Semerci A, Cobb N (2010) A global overview of drought and heat-induced tree mortality reveals emerging climate change risks for forests. For Ecol Manag 259(4):660-684. https://doi.org/10.1016/j.foreco.2009.09.001

68. Melillo JM, Richmond TC, Yohe GW (eds) (2014) Climate change impacts in the United States: The Third National Climate Assessment. U.S. Global Change Research Program. https://doi.org/10.7930/J0Z31WJ2.

69. Westerling AL, Hidalgo HG, Cayan DR, Swetnam TW (2006) Warming and earlier spring increase western U.S. forest wildfire activity. Science 313(5789): 940-943. https://doi.org/10.1126/science.1128834

\section{Submit your manuscript to a SpringerOpen ${ }^{\circ}$ journal and benefit from:}

- Convenient online submission

- Rigorous peer review

- Open access: articles freely available online

- High visibility within the field

- Retaining the copyright to your article

Submit your next manuscript at $\gg$ springeropen.com 